\title{
Influences of the program for access and quality improvement in work processes in primary care
}

\author{
Influências do programa de melhoria do acesso e qualidade \\ nos processos de trabalho na atenção básica \\ Influencias del programa de mejoría del acceso y calidad en \\ los procesos laborales en la atención básica
}

Lucilene Renó Ferreira ${ }^{1}$, João Antônio da Silva Júnior'², Thaís Arrigotti², Vanessa Ribeiro Neves ${ }^{3}$, Anderson da Silva Rosa ${ }^{4}$

How to cite this article:

Ferreira LR, Silva Júnior JA, Arrigotti T, Neves VR, Rosa AS. Influences of the program for access and quality improvement in work processes in primary care. Rev Esc Enferm USP. 2018;52:e03407. DOI: http://dx.doi.org/10.1590/S1980-220X2017046403407

${ }^{1}$ Universidade Federal de São Paulo, Escola Paulista de Enfermagem, Programa de PósGraduação em Enfermagem, São Paulo, SP, Brazil

2 Universidade Federal de São Paulo, Escola Paulista de Enfermagem, São Paulo, SP, Brazil.

${ }^{3}$ Universidade Federal de São Paulo, Escola Paulista de Enfermagem, Departamento de Administração em Serviços de Saúde e Enfermagem, São Paulo, SP, Brazil.

${ }^{4}$ Universidade Federal de São Paulo, Escola Paulista de Enfermagem, Departamento de Saúde Coletiva, São Paulo, SP, Brazil.

\begin{abstract}
Objective: To assess the perception of professionals of Family Health Strategy Teams on the National Program for Access and Quality Improvement in Primary Care and the possible changes in the work processes resulting from its implementation. Method: Oral history methodology conducted with members of Basic Health Units' teams who participated in the first two cycles of the Program in São Paulo. Results: Six team members participated in the research. The professionals described the use of information to support the planning, diverged on the changes in the organization of the service and identified contributions to the direction of the teams and the control of the activities. The implementation of the Program led to changes in professional practice and favored autonomy and teamwork. The Community Health Workers stood out in the information acquisition process, and the teams found difficulties to organize the information. The collection and retrieval of information contributed to broaden the professionals' view of the service, and the interviewees criticized the fragility of information dissemination in the Units. Conclusion: Despite its limitations, the Program led to direct improvements in the work of the teams in Primary Care.
\end{abstract}

\section{DESCRIPTORS}

Primary Health Care; Health Evaluation; Program Evaluation; Health Services Administration; Health Information Management. 


\section{INTRODUCTION}

Primary Health Care (PHC) is the preferred gateway to the public health system in Brazil, within the scope of the Unified Health System (SUS - Sistema Único de Saúde). The PHC includes health prevention and promotion, diagnosis, treatment and rehabilitation, which are carried out in the Basic Health Units (BHU) within the territories assigned to them. These actions should be directed to the reality of the local population and must follow the principles and guidelines of the SUS ${ }^{(1)}$.

In this scenario, the evaluation of the outcomes and the quality of the services offered in PHC is an important basis for decision-making and it also serves to improve the service offered to the population, considering that there are political issues and values intrinsic to the service and to the workers and that its application requires the use of well-designed instruments appropriate to the local reality. In addition, this service requires the involvement of all professionals in order to make decisions and use the results to improve work processes $^{(2)}$.

The work process is understood as the transformation of an object or action into a product or service with the use of certain instruments and with the purpose of generating something that is valuable for the human being ${ }^{(3)}$. The healthcare work process occurs through the relationship between individuals and between individuals and the environment, combines cooperation with the use of knowledge and technology, and results in services that are offered and consumed at the same time ${ }^{(4)}$. These characteristics demonstrate the complexity and the importance of the evaluation of these processes in the different levels of health care.

Many initiatives have tried to implement effective evaluation programs in PHC. As a proposal of a structured program with objective criteria, in 2011 the federal government created the National Program for Access and Quality Improvement in Primary Care (PMAQ-PHC), organized in three phases - Participation and Contracting; Certification; and Contract Renewal - and a strategic development axis, which form a continuous cycle of PHC access and quality improvement ${ }^{(5)}$. It is a performance evaluation model that "aims to measure the possible effects of the health policy in order to support decision making, ensure transparency of the management processes in the SUS and generate visibility to the results achieved, as well as strengthen social control and the health system's focus on users"(6).

The evaluation and the use of strategies that improve the quality and decisiveness of primary care services is a concern in several countries of the world ${ }^{(7-10)}$. In Brazil, where it is necessary to expand access to the health system, the PMAQ$\mathrm{PHC}$ has contributed to the identification of needs and implementation of improvements ${ }^{(11)}$. Despite its relevance, there are gaps in scientific production on the influence of the Program on the work processes in PHC. Studies with this theme become relevant references for the identification of the strengths and weaknesses of the Program and can support reflection on the effectiveness of the actions proposed by it and favor the improvement of professional practice.
Thus, this study aimed to assess the perception of professionals of Family Health Strategy Teams on the PMAQ$\mathrm{PHC}$ and the possible changes in the work processes resulting from the implementation of the Program.

\section{METHOD}

\section{TYPE OF STUDY}

The oral history methodology was used in this study. This methodology allows understanding and recording in written statements the experiences reported by significant individuals or groups on a certain topic ${ }^{(12)}$. Thus, members of the Family Health Strategy Teams who could narrate their experiences during the PMAQ-PHC development process in their respective $\mathrm{BHU}$ were interviewed.

\section{SCENARIO}

The study was carried out in the city of São Paulo, in an administrative district composed of 15 BHUs and covered by the Family Health Strategy (FHS). The implementation of the PMAQ-PHC in these units occurred with a shared management, social control and active participation of the teams, who had daily meetings. All units had a Family Health Support Center (FHSC) and institutional support from the Regional Health Coordination and the Social Health Association (SHA) responsible for the management of the district.

\section{Population}

The subjects selected to participate in this study were the members of this district's FHS who directed the work of teams in the BHU during all stages of the PMAQ-PHC and acted in the first and second adhesion cycle of the Program, which started respectively in 2011 and $2013^{(12)}$. The use of these criteria in the studied territory led to the identification of six professionals - five nurses and one physician - from five BHU. All were included in the research and are referred to in the text as E1, E2, E3, E4, E5 and E6. There was no indication of other professional categories that acted in the coordination of PMAQ-PHC's actions.

\section{DATA COLLECTION}

The data were collected between August 2016 and February 2017 through semi-structured interviews, conducted by one of the authors in reserved rooms at the workplace of each participant. The questions in the script for the interviews were: "How do you evaluate the PMAQ-PHC process in this BHU?" And "Did the PMAQ-PHC influenced your work process and your teams? In what way?". The interviews lasted approximately 1 hour and were recorded in audio format and transcribed in full by the researchers.

\section{DATA ANALYSIS}

Data analysis followed the steps: 1 . Reading and re-reading of the transcribed material, searching for guiding topics for the organization of the information; 2. Textualization of the discourses, with the incorporation of the questions asked 
during the interviews to the narrators' discourses and the approximation of the texts that addressed the same topic; 3. Codification of excerpts from the discourses, according to the topics addressed in them, for the identification of the unit of meaning; and 4. analysis of the content of the discourses and definition of thematic groups, according to the thematic analysis model proposed by Minayo ${ }^{(13)}$. For the construction of thematic and analytical categories, the similarity, pertinence and equivalence between the themes found through the codification process were evaluated.

Two categories emerged from the analysis of the discourses: The PMAQ-PHC and work processes at the BHU and The PMAQ-PHC and the management of health information. The categories were presented, interpreted and discussed in the light of the scientific literature on the subject.

\section{ETHICAL ASPECTS}

All the interviewees signed the Informed Consent Form. The research project was approved by the Research Ethics Committee of the Universidade Federal de São Paulo, protocol no. 1.402 .862 and by the Research Ethics Committee of the Municipal Health Department, protocol no. 1.473.641.

\section{RESULTS}

The interviewees, five females and one male, had a mean age of 50 years old and a mean of 19 years since graduation in higher education and 12 years of work in FHS. Three of them were specialists in Family Health, and the mean time of work in these BHU at the time of the interview was 8 and a half years.

\section{THE PMAQ-PHC AND THE WORK PROCESSES IN THE BHU}

Most of the participants pointed to the use of the information obtained through the Program to support planning in the BHU.

We do the planning at the beginning of the year, (...) we already set a date for the reassessment of what is happening: What are you achieving? What have you not been able to achieve? What has progressed? What has stopped? What can improve? Where do you need to improve? With the information from $P M A Q$, we had a lot of things that best suited this outcome (E5).

At the end of the year, we always review, we take all the charts, see who passed, who did not, why did it happen (...). We have everything mapped out. (...) hospitalizations, deaths, causes, new bypertension case. (...) With all that, it's easy for you to plan (E4).

The subjects presented divergent opinions regarding the influence of PMAQ-PHC in the organization of the service. Some of them reported that their administrative function became easier with the implementation of the Program, unlike Interviewee 3, who was not sure of this relationship in their workplace.

We use the charts for everything, they help in the organization of work (E1).

The PMAQ was an organizer for the team, because it creates a different concept of everything and organizes the work all the time (E6).
For the Unit and for the teams, the Program helped in the organization, because each one used to do things as they wanted, and the program standardized it. Even if I'm doing what I want, I can maintain a standard and, within this pattern, I develop the best way to maintain this service (E4).

As a team, we tried to organize ourselves, but there are other sectors of the Unit that have also changed, and you do not know if what has changed, what improved, was an impact of the Program or not (E3).

According to the interviewees, the PMAQ-PHC contributed to the direction of the teams in the BHU.

I think it [PMAQ-PHC] gave focus, direction to us who are here. We were even questioned (by the team): Why do you pester us so much? (E2).

I'm really strict, I plan, I observe, so I had no difficulty to implement it [the Program], nor to follow up. We end up setting priorities on top of that. (...) the community health service had no feedback from the team, it did not know [what was happening]. I called the pregnant woman, it had no interest. It started to get interested because it started to see that the pregnant woman does not come, because I report that the pregnant woman did not come, so it will have to go there to warn the pregnant woman, the bypertensive (E4).

An increase in control of the activities carried out in the BHU was pointed out by the majority of the participants as a result of the PMAQ-PHC. They also reported the benefits of this practice for monitoring the work and for finding solutions.

Today we have well-controlled charts of patient who use psychotropic drugs, for example. Currently, I follow the adolescents. I see that some teams do not. This is a work from our team that I see it's still in baby steps, but I have a good answer, I can visualize our work (E2).

We did a lot of things, and sometimes we did not really know what was happening. With the charts, we have a much better follow up. (...) this made it a lot easier for us, it helped us to see the adjustments we have to make (E5).

The charts that we have set up from $P M A Q$, which we feed every day, every week, with the differences, that's how we know... we know that through the PMAQ, through all these controls that we have, our people can invest more in what the population needs (E1).

I think it was better after the $P M A Q$, because we know best where we fail. And when we find the problem, we try to solve it (E6).

According to the interviewees, the implementation of the PMAQ-PHC supported reflection among the members of the teams and encouraged changes in the work they performed in the Units.

With PMAQ, my work as a nurse has changed. I see improvements that we often fail to appreciate on our regular practice. But, over time, you say: This year has passed. What did I do? What did I fail to do? This reflection makes us better (E2).

The PMAQ reminds me of a lot of things that we must take care of. No, this is not good yet, we have to solve it, we have to take care of it (E6). 
Sometimes we want to do something new, because something is not working, (...) then ideas begin to emerge. And those who have more ideas are the workers, because they are there every day, observing [the users and the territory]. Then you have an idea, and they say: It will not work because of this and that. (...) It's not because they do not want to do it, it's because at that moment it cannot be done because something else is happening. We do that (E4).

Part of these changes, according to the interviewees, was related to the perception of the value of work, especially by the community health workers (CHW), who did not have this vision before the Program.

The CHW does not know that his work has a global impact, so you have to work on this perception. I think that for them it is a more difficult question, and it needs to be stimulated in some way (E3).

The fact that a bypertensive patient did not come [to the BHU] and was being treated out there was okay for him [the CHW], he had no problem with it... [But] if a young woman of childbearing age, bypertensive, dies there, they're coming after us, and they saw that. [Now] they do not know how to work without a chart and they have begun to see the importance of their work (E4).

The Program helps the CHW to see the importance of their work and, with this, the team is strengthened as well (E6).

In fact, nobody noticed the things that he did, because it [the work] was very regular, usual. The Program helped a lot, because it showed some things that we could not see, and with that, we were able to value our work (E2).

This visibility attributed to participation in the Program favored the empowerment of the teams, according to Interviewee 2, and offered support to its members.

We always worked, but often we could not certify and take over our work, because there was no data, there was no chart for proper follow-up. With the Program, this has improved a lot, but I believe it could still support us better (E2).

There is no denying, even with so much charts and so much to write, it is in the PMAQ that we are backed up (E1).

Thus, according to Interviewee 4 , the teams became autonomous to decide and incorporate the changes that emerged with the development of PMAQ-PHC.

Since we started the PMAQ, I tell my team that they are managers of their territory, because this is important to them. We have a motto on our team that is like: Do you know why you are from Area 1? and they answer: Because Area 1 decides! (...) They have the autonomy to decide within their territory and to bring the answer to us (E4).

The interviewees also affirmed that the Program facilitated the work within the teams and between the different teams in the Units and emphasized the integration resulting from the self-assessment.

At first, we wondered if it was one more thing to give us more work and no results, but then we realized that the implementation of the Program had a good effect on the team's work (E5).

Feedings the charts were something the teams had great difficult with, but it was worth it. The workers had more difficulties, but everyone got together, one helping the other, and it worked out (E1).
Teams evolve together, and I think that's a consequence of PMAQ (E6).

We read the entire $P M A Q$ book, the $A M A Q$, as a team, and everyone responded together, to reach consensus. It was cool (E6).

We noticed that sometimes people looked in very different directions and we had to look in a single direction. With self-evaluation, this integration is better and this is important (E5).

\section{The PMAQ-PHC and the MANAgement OF HeAlth INFORMATION}

The CHW were pointed out by the interviewees as the main responsible for the information acquisition process in the BHU. The participants also mentioned the need to educate these professionals about the importance of the work they perform.

They [the CHW] are the ones who collect information. (...) And that's what we're working on (E1).

They [the CHW] gather this information. I think they are unaware of the importance of this work, they don't know why. If we emphasize it, they can become aware of their work (...) and this way we can bring them closer to the work process (E6).

The team was also described as an important source of information acquisition and sharing in the BHU.

(...) the team gathers this data and passes it to another sector of the BHU, which fortifies them (E3).

The discourses demonstrated the difficulties presented by the professionals regarding the organization of information in the Units. Excessive number of charts and work overload were mentioned as problems.

Charts, more charts, more charts. And it is always increasing, there is no way. (...) There is so much to write... (E1).

What is harder for us is to feed these charts. (...) We have weekly team meetings, and we have a lot of things to discuss and a lot of things to fill. We cannot feed these charts on a daily basis, so sometimes we are short on some things, but we adjust it (E5).

Creating charts is easy. Feeding charts is the hardest thing we have to do, because our work is not linear (E3).

The personal interest of the professionals in organizing the data and the need to understand the usefulness of this process were also reported by Interviewee 3 .

[The difficulty of] feeding [the charts] is a major problem. (...) It depends on your personal interest, if you have a personal interest in doing this, you assemble, you elaborate, you do it. I think that for the community worker the problem is that they have no idea of the outcome of their work (E3).

Faced with these difficulties, the interviewees sought ways to facilitate the organization of information, as shown in the following excerpts:

We have staff that feeds (the charts) in the meetings, there are people who feed it every day. It is easier for the teams that remain until the last shift, from 4 p.m. to 6 p.m., because it is a slack period. But the teams that come in at 7 a.m.... At 7 a.m. it is crowded! At noon we have the consultations. So, we're short on time even to do the statistics. In that sense, I think you need 
to identify the differences between the teams and how they can deal with that process to get a feedback (E5).

When home visits are advanced, we can advance (in filling out the charts) (E5).

The protocols have to be created and fed by the entire BHU, they cannot be left to the discretion of only one team (E3).

The lack of standardization in data organization was mentioned by Interviewee 6 .

Nurses love a chart [laughs]. And we accumulate a lot of notebooks, books, everything has to have a chart, we do it this way. If you ask any of the nurses, each one has their own way of writing down information. But everyone has their situation organized and the PMAQ facilitated this (E6).

According to Interviewee 3 , the collection and retrieval of information allowed an expanded view regarding the service offered and the needs and possibilities for improvement.

I like data. (...) You often do not have a clear vision, and having numbers is one of the best ways to see why you cannot do certain things. (...) there are many data that you could collect and save and that would serve, in the future, for comparisons, indexes. I think this is very productive (E3).

Interviewee 6 pointed out, however, that it is difficult to recover certain information during the Program.

The first time I was interviewed at PMAQ, (...) I still remember one of the questions: Do you have any idea how many male condoms were taken in your area? I said I do not, and he said: But you have to know that. In my team, there is no way for me to know (E6).

The perception about the fragility of the dissemination of information in the BHU was unanimous among the interviewees. The discourses demonstrated the limited use of the data regarding the results obtained by the teams as feedbacks for their professional practice.

The bigger problem, regardless of whether or not $P M A Q$ exists, is that we collect data, but the data does not come back to us. We can't complete this cycle. We do not have an improvement or worsening report: Look, in our area, this improved, that regressed. We do not have an evaluation of the outcomes of our work. It is impersonal, it is very loose. If I do not have indexes to work on, how am I going to work these indexes in my region? How will I do the calculations for my area? It is data that we gathered and that has gone somewhere, but there is no agility in the feedback. (...) We must see the results (E3).

For this reason, according to the interviewees, the members of the teams started to question the usefulness of the management of this information in the Units.

We fill these charts, but sometimes we do not really know the purpose of doing it. (...) It is important to know what the purpose is and why it is important to do it that way, I always try to work like this (E2).

\section{DISCUSSION}

The participation of graduated professionals who worked in the two cycles of the PMAQ-PHC as selection criteria for this study revealed, indirectly, the turnover of physicians in the FHS. Research on this topic identified greater turnover of physicians in the Southeastern and Southern regions of Brazil as a result of a more competitive labor market, social organization management model, higher salaries and different incentives to attract these professionals ${ }^{(14)}$.

A study with 17,482 FHS that adhered to the PMAQPHC in 3,972 Brazilian cities highlighted the singular position of the nurse in the $\mathrm{PHC}$ team, pointing to the expansion of the limits of their professional performance and addition of administrative activities to their practices of direct assistance to the user. As the present study demonstrates, "the nurse has assumed a cognitive authority role in flow of information about the work organization process", linked to the PMAQ-PHC ${ }^{(15)}$.

The institutionalization of evaluation is one of the most important challenges for health systems today ${ }^{(16-17)}$. Systematized evaluation processes can and should support management in planning, execution, monitoring, politicalinstitutional decisions, allocation of resources, and construction of guidelines capable of increasing the efficiency and effectiveness of PHC and SUS Health Care Networks ${ }^{(18)}$.

It is essential to reflect about the quality of PHC services, considering they have a structural function in a health system responsible for the decisiveness and coordination of care throughout the service network. Innovative practices have been used to qualify actions aimed at quality improvement, as demonstrated in a US study carried out with primary care professionals, which identified the presence of an expanded team, with the work of nursing practitioners in the support for self-care, management of chronic diseases and health orientations, directing of medical activities, with autonomy and acting under protocols, working in community, among other actions ${ }^{(7)}$.

The present study found similar data, as professionals valued teamwork and unanimously acknowledged the strategic importance of the CHW as a link between the community and the teams. They also recognized their assertiveness in the collection of health data for the evaluation processes and the autonomy they acquired when they became aware of their work through the PMAQ-PHC. The recently introduced text, which changed the National Primary Care Policy (PNAB - Politica Nacional de Atenção Básica) ${ }^{(1)}$, makes the presence of CHW in FHS more flexible and gives new responsibilities to these professionals, such as measuring blood pressure and glycemia, reigniting the discussion about the work of the $\mathrm{CHW}$. Despite the importance of this professional to PHC, these deliberations can take away the peculiarity of their performance and, over time, decrease their presence in the teams.

The results agreed with a study carried out in Campinas, SP, addressing the work production and workers' performance based on the PMAQ-PHC proposal and documents. The implementation of the Program in assistance, the democracy in management, the remuneration and motivation of professionals, the evaluations of workers' performance, and reflections on autonomy and empowerment at work were the main subjects discussed ${ }^{(19)}$, and the last three are the ones that most resemble the findings of the present study.

The systematized evaluation of the daily practice, encouraged by the PMAQ-PHC, allows professionals to identify 
necessary changes, as subjects integrated into the SUS. From the results, it was possible to observe potential for work processes more directly related to the priority needs of the production of health actions in the BHU studied. Ensuring the autonomy of the teams favors the influence of social, cultural, historical and political aspects in the work processes and in the relationship with the community, in the search for the desired outcomes.

Considering the management of the work process in $\mathrm{PHC}$, it is necessary to create alternatives to overcome fragmented practices and to reduce the disconnection between formulators and implementers of health actions, the triviality of repetitive tasks, the overload of work, the punitive character of performance supervisions, the fragility of the communication between different management and assistance levels and the challenges in improving the practice based on the results of evaluations ${ }^{(18)}$.

Work processes centered on a "health production care model" should "be based on the production of care, with emphasis on teamwork, humanization of care and ethics of responsibility"(4). In this sense, the workers who participated in this study reported that, with the implementation of PMAQ-PHC, the dialogue, reflection and collective construction of strategies to meet the demands of users and of the community began to be addressed.

All the interviewees associated the PMAQ-PHC with health information management, which includes data flows and their articulation with the decision-making and the evaluation process ${ }^{(20)}$. A similar result was found in a study on the PMAQ-PHC, carried out in Natal, a city in the Northeastern region of Brazil, which identified the organization of work and of records as two of the main changes arising from the Program ${ }^{(11)}$.

The most pressing perception of the interviewees, also highlighted in a study on professional dissatisfaction ${ }^{(21)}$, refers to the workload arising from collecting data and feeding charts, despite their acknowledgment of the importance of this information for the evaluation of the needs of the community, of the results of the actions carried out and of the possibilities for improvement ${ }^{(8)}$. There was also unanimity regarding the fragility in the dissemination of the information gathered by the teams in the BHU itself, limiting the potential for improvement in access and quality, objectives of the Program, and destimulating the team, who cannot visualize the results achieved.

A study ${ }^{(11)}$ pointed out the financial incentive to the teams that participate in the PMAQ-PHC as a positive strategy for the motivation of professionals. However, the contract made in the city of São Paulo did not provide additional remuneration to the workers, which indicates the disparities in the municipal management of PHC in Brazil.

PHC was constructed with the perspective of planning and executing actions based on the analysis of the territory and of the health needs of the population. To do so, it is based on information management, which guarantees the quality of the care provided to people and to the community, integrates care and management activities and improves the results of services. In this sense, the use of the Primary
Attention Information System (SIAB) as a management tool of Local Health Systems can be highlighted. In 1998, this system incorporated concepts such as territory, problem and sanitation responsibility ${ }^{(22)}$.

Results regarding the use of SIAB since the implementation of the PMAQ-PHC demonstrated the need to invest in technological resources and training and incentive of professionals and managers for the use of information in daily work and planning ${ }^{(23)}$. In 2013, the SIAB was gradually replaced by the Primary Health Information System (SIS-PHC) ${ }^{(24)}$, a strategy developed by the Ministry of Health $(\mathrm{MH})$ to expand and improve the availability of information needed to plan and evaluate actions in the entire national territory. This became the information system in force throughout the country since $2016^{(25)}$.

The results of this study showed that the professionals of the health teams are gradually incorporating the information management resulting from the PMAQ-PHC to support the planning of their actions and to qualify the technical and administrative processes under their responsibility. Perhaps, in this way, they are prioritizing more urgent or previously neglected demands, constructing possible interventions for local realities and contributing to the better functioning of the health system.

It is worth noting that the city of São Paulo, area of this study, opts for the use of its own information management system, which is focused on the partial transfer of data and integration with the official $\mathrm{MH}$ system. This fact may explain part of the participants' perception on the lack of standardization and organization in the information management process. The variables technological structure, use of information systems (including electronic medical records), use and availability of information in the systems, among others, were associated in a study that evaluated the technological incorporation within the framework of PMAQ-PHC. The most populous cities in the South and Southeast regions showed greater technological incorporation, associated with better results in the performance of FHS in the Program ${ }^{(26)}$.

Based on the results regarding the work of the teams after the implementation of the PMAQ-PHC, we identified that the stages of the Program, mainly the self-assessment, have provided reflections and knowledge about the work of the teams and promoted improvements in the quality and convergence of actions aimed at reaching the goals of the management of the BHU. Another relevant aspect is the perception of improvement in the relationship between professionals, their personal valuation and the autonomy with which professionals perform their activities, factors that contribute to professional satisfaction and to the quality of service offered to users ${ }^{(11,21)}$.

A study carried out in seven European countries evaluated the satisfaction of primary care professionals and, despite the fact that it was specifically aimed at the medical category and characterized by the diversity of models and services, it revealed association between professional satisfaction and years of experience, integrated network of primary care centers and direct access and exchange of information with specialized 
professionals ${ }^{(27)}$. This study also indicated an increase in autonomy and knowledge as a consequence of factors such as professional practice, the existence of spaces for exchanging knowledge with other professionals, the feedback about the care provided and the use of patient information to support integrated care ${ }^{(9,27)}$. The relevance of information sharing was also pointed out in the present study, specifically in relation to the service offered and the needs for improvements in the units, which is a challenge faced by the teams and a crucial step for the acquisition and organization of information to improve the quality of the service.

In addition to the availability of information exchange spaces, the training of professionals also provides good results, according to a study carried out in Scotland with primary care teams, which consisted in the implementation of a pilot project to evaluate the quality of care, conducted collaboratively for 2 years. The results of this study had an impact on the acquisition of theoretical and practical knowledge, the attribution of importance to the work and care environment where they were inserted, the feedback about the care offered, the quality of the protocols and the use of patient information systems ${ }^{(10)}$, experiences that point out a way for the teams to understand the need to manage information in the units, a fragility identified by the interviewees of the present study.

Similarly, in an effort to restructure primary care, Portugal focused on teamwork, reduced staff numbers, computerized and well-structured services, establishments of goals, objectives and action plans with technical and care management autonomy, quality of access and assistance, and satisfaction of professionals and workers ${ }^{(28)}$.
Finally, despite the differences between the countries mentioned, there are common elements that support the structuring of $\mathrm{PHC}$, the organization of work processes and the precision of the evaluation criteria, the same ones sought in Brazil.

Because the methodological design does not imply generalizations, the fact that the results represent local experiences of an administrative district and local strategies adopted for the implementation of the PMAQPHC can be pointed out as limitations of the study. Digressions on the theme of the study in national or international studies must consider the possible influences of each conjuncture.

\section{CONCLUSION}

In Brazil, evaluation is not always incorporated into the services and is seen as a bureaucratic action, not useful for the decisions and training of professionals. Therefore, it is necessary to institutionalize evaluation processes in order to qualify and organize a model of primary health care with greater decisiveness. The present study indicates that the PMAQ-PHC represents an advance in this direction.

The professionals' perception about the PMAQ-PHC indicates direct improvements in the work processes of the teams and in the management of health information, since it has allowed reflection, self-assessment, planning, integration among professionals and convergence in the actions carried out by the team. On the other hand, they point out the workload, the large amount of information to be collected and the weaknesses in the dissemination of the results to the teams as factors that limit the Program's potential to qualify the actions in PHC.

\section{RESUMO}

Objetivo: Conhecer a percepção de profissionais de Equipes de Saúde da Família quanto ao Programa Nacional de Melhoria do Acesso e da Qualidade da Atenção Básica e às possíveis mudanças nos processos de trabalho decorrentes da sua implementação. Método: História oral temática com integrantes de equipes de Unidades Básicas que participaram dos dois primeiros ciclos do Programa em São Paulo. Resultados: Participaram seis integrantes de equipes. Os profissionais descreveram a utilização de informações para fundamentar o planejamento, divergiram quanto às mudanças na organização do serviço e identificaram contribuições para a direção das equipes e o controle das atividades. A implementação do Programa propiciou mudanças na prática profissional e favoreceu a autonomia e o trabalho em equipe. Os Agentes Comunitários de Saúde destacaram-se no processo de coleta de informações, e as equipes apresentaram dificuldades para organizá-las. $\mathrm{O}$ armazenamento e a recuperação de informações contribuíram para ampliar a visão dos profissionais quanto ao serviço, e os entrevistados criticaram a fragilidade da disseminação de informações nas Unidades. Conclusão: A despeito de suas limitações, o Programa propiciou melhorias diretas no trabalho das equipes na Atenção Básica.

\section{DESCRITORES}

Atenção Primária à Saúde; Avaliação em Saúde; Avaliação de Programas e Projetos de Saúde; Administração de Serviços de Saúde; Gestão da Informação em Saúde.

\section{RESUMEN}

Objetivo: Conocer la percepción de profesionales de Equipos Sanitarios de la Familia en cuanto al Programa Nacional de Mejoría del Acceso y la Calidad de la Atención Básica y a los posibles cambios en los procesos laborales consecuentes de su implantación. Método: Historia oral temática con integrantes de equipos de Unidades Básicas que participaron en los dos primeros ciclos del Programa en São Paulo. Resultados: Participaron seis integrantes de equipos. Los profesionales describieron la utilización de informaciones para fundamentar la planificación, divergieron en cuanto a los cambios en la organización del servicio e identificaron los aportes para la dirección de los equipos y el control de las actividades. La implantación del Programa proporcionó cambios en la práctica profesional y favoreció la autonomía y el trabajo en equipo. Los Agentes Comunitarios de Salud se destacaron en el proceso de recolección de informaciones, y los equipos presentaron dificultades para organizarlas. El almacenamiento y la recuperación de informaciones contribuyeron a ampliar la visión de los profesionales en cuanto al servicio, y los entrevistados criticaron la fragilidad de la diseminación de informaciones en las Unidades. Conclusión: A despecho de sus limitaciones, el Programa proporcionó mejorías directas en el trabajo de los equipos en la Atención Básica.

\section{DESCRIPTORES}

Atención Primaria de Salud; Evaluación en Salud; Evaluación de Programas y Proyectos de Salud; Administración de los Servicios de Salud; Gestión de la Información en Salud. 


\section{REFERENCES}

1. Brasil. Ministério da Saúde. Portaria n. 2436, de 21 de setembro de 2017. Aprova a Política Nacional de Atenção Básica, estabelecendo a revisão de diretrizes para a organização da Atenção Básica, no âmbito do Sistema Único de Saúde (SUS). Diário Oficial da União, Brasília, 22 set. 2017. Seção 1, p. 68.

2. Tanaka OU, Tamaki EM. O papel da avaliação para a tomada de decisão na gestão de serviços de saúde. Ciênc Saúde Coletiva [Internet]. 2012 [citado 2017 set. 26];17(4):821-8. Disponível em: http://www.scielo.br/pdf/csc/v17n4/v17n4a02.pdf

3. Marx K. O capital: crítica da economia política. Livro I: O processo de produção do capital. São Paulo: Boitempo; 2013.

4. Chagas HMA, Vasconcellos MPC. When the entrance does not solves: analysis of the health family units in the city of Rio Branco, Acre. Saúde Soc [Internet]. 2013 [cited 2018 Mar 4]; 22(2):377-88. Available from: http://www.scielo.br/pdf/sausoc/v22n2/en_v22n2a10.pdf

5. Brasil. Ministério da Saúde; Secretaria de Atenção à Saúde, Departamento de Atenção Básica. Programa Nacional de Melhoria do Acesso e da Qualidade da Atenção Básica (PMAQ) - terceiro ciclo: manual instrutivo para as Equipes de Atenção Básica e NASF [Internet]. Brasília; 2017 [citado 2017 mar. 8]. Disponível em: http://189.28.128.100/dab/docs/portaldab/documentos/Manual_ Instrutivo_3_Ciclo_PMAQ.pdf

6. Brasil. Ministério da Saúde; Secretaria de Atenção à Saúde, Departamento de Atenção Básica. Programa Nacional de Melhoria do Acesso e da Qualidade da Atenção Básica (PMAQ): manual instrutivo [Internet]. Brasília; 2012 [citado 2018 jul. 10]. Disponível em: http://bvsms. saude.gov.br/bvs/publicacoes/manual_instrutivo_programa_acesso_atencao_basica_site.pdf

7. Wagner EH, Flinter M, Hsu C, Cromp D, Austin BT, Etz R, et al. Effective team based primary care: observations from innovative practices. BMC Fam Pract [Internet]. 2017 [cited 2017 May 18];18:13. Available from: https://www.ncbi.nlm.nih.gov/pmc/articles/PMC5289007/

8. Bailie R, Matthews V, Brands J, Schierhout G. A systems-based partnership learning model for strengthening primary healthcare. Implement Sci [Internet]. 2013 [cited 2018 Mar 08];8:143. Available from: https://www.ncbi.nlm.nih.gov/pmc/articles/PMC3878728/

9. Papp R, Borbas I, Dobos E, Bredehorst M, Jaruseviciene L, Vehko T, et.al. Perceptions of quality in primary health care: perspectives of patients and professionals based on focus group discussions. BMC Fam Pract [Internet]. 2014 [cited 2017 May 13];15(128). Available from: https://www.ncbi.nlm.nih.gov/pmc/articles/PMC4083126/

10. Bowie P, Halley L, Blamey A, Gillies J, Houston N. Qualitative evaluation of the Safety and Improvement in Primary Care (SIPC) pilot collaborative in Scotland: perceptions and experiences of participating care teams. BMJ Open [Internet]. 2016 [cited 2017 Aug 19];6:e009526. Available from: https://www.ncbi.nlm.nih.gov/pmc/articles/PMC4735198/

11. Feitosa RMM, Paulino AA, Lima Júnior JOS, Oliveira KKD, Freitas RJM, Silva WF. Changes offered by the National Program for Improving Access and Quality of Primary Care. Saúde Soc [Internet]. 2016 [cited 2018 Mar 04];25(3):821-29. Available from: http://www.scielo. br/scielo.php?script=sci_arttext\&pid=S0104-12902016000300821\&lng=en\&nrm=iso\&tlng=en .

12. Meihy JCS, Holanda F. História oral: como fazer, como pensar. São Paulo: Contexto; 2010.

13. Minayo MCS. O desafio do conhecimento: pesquisa qualitativa em saúde. São Paulo: Hucitec; 2014.

14. Pierantoni CR, Vianna CMM, França T, Magnago C, Rodrigues MPS. Rotatividade da força de trabalho médica no Brasil. Saúde Debate [Internet]. 2015 [citado 2018 mar. 05];39(106):637-47. Disponível em: http://www.scielo.br/scielo.php?pid=S0103$11042015000300637 \&$ script=sci_abstract\&tlng=pt

15. Galavote HS, Zandonade E, Garcia ACP, Freitas PSS, Seidl H, Contarato PC, Andrade MAC, Lima RCD. The nurse's work in primary health care. Esc Anna Nery [Internet]. 2016 [cited 2018 Mar 2];20(1):90-8. Available from: http://www.scielo.br/pdf/ean/v20n1/en_1414-8145ean-20-01-0090.pdf

16. Carvalho ALB, Shimizu HE. The institutionalization of monitoring and evaluation practices: challenges and prospects in the view of the Brazilian National Health System managers. Interface Comun Saúde Educ [Internet]. 2017 [cited 2017 Oct 8];21(60):23-33. Available from: http://www.scielo.br/pdf/icse/v21 n60/en_1807-5762-icse-1807-576220150817.pdf

17. Protasio APL, Gomes LB, Machado LS, Valença AMG. User satisfaction with primary health care by region in Brazil: 1 st cycle of external evaluation from PMAQ-AB. Ciênc Saúde Coletiva [Internet]. 2017 [cited 2017 June 19];22(6):1829-44. Available from: http://www.scielo. $\mathrm{br} / \mathrm{pdf} / \mathrm{csc} / \mathrm{v} 22 \mathrm{n6} / \mathrm{en} \_1413-8123$-csc-22-06-1829.pdf

18. Medrado JRS, Casanova AO, Oliveira CCM. Estudo avaliativo do processo de trabalho das Equipes de Atenção Básica a partir do PMAQAB. Saúde Debate [Internet]. 2015 [citado 2017 out. 3];39(107):1033-43. Disponível em: http://www.scielo.br/pdf/sdeb/v39n107/01031104-sdeb-39-107-01033.pdf

19. Moraes PN, Iguti AM. Avaliação do desempenho do trabalhador como forma peculiar de prescrição do trabalho: uma análise do PMAQ-AB. Saúde Debate [Internet]. 2013 [citado 2017 mar. 30];37(98):416-26. Disponível em: http://www.scielo.br/pdf/sdeb/v37n98/a05v37n98.pdf

20. Santos CD, Valentim MLP. As interconexões entre a gestão da informação e a gestão do conhecimento para o gerenciamento dos fluxos informacionais. Perspect Gestão Conhec [Internet]. 2014 [citado 2017 maio 13];4(2):19-33. Disponível em: http://periodicos.ufpb.br/ ojs2/index.php/pgc

21. Soratto J, Pires DEP, Trindade LL, Oliveira JSA, Forte ECN, Melo TP. Job dissatisfaction among health professionals working in the Family Health Strategy. Texto Contexto Enferm [Internet]. 2017 [cited 2017 Oct 5];26(3):e2500016. Available from: http://www.scielo.br/pdf/tce/ v26n3/en_0104-0707-tce-26-03-e2500016.pdf

22. Carreno I, Moreschi C, Marina B, Hendges DJB, Rempel C, Oliveira MMC. Análise da utilização das informações do Sistema de Informação de Atenção Básica (SIAB): uma revisão integrativa. Ciênc Saúde Coletiva [Internet]. 2015 [citado 2017 out. 2];20(3):947-56. Disponível em: http://www.scielo.br/pdf/csc/v20n3/1413-8123-csc-20-03-00947.pdf

23. Cavalcante, RB, Bernardes MFVG, Gontijo TL, Guimarães EAA, Oliveira VC. Sistema de Informação da Atenção Básica: potencialidades e subutilização no processo decisório. Cogitare Enferm [Internet]. 2013 [citado 2017 fev. 16];18(3):460-7. Disponível em: http://www. redalyc.org/pdf/4836/483649281006.pdf

24. Brasil. Ministério da Saúde. Portaria n. 1976, de 12 de setembro de 2014. Altera e acrescenta dispositivos à Portaria n 1.412/GM/MS, de 10 de julho de 2013. Diário Oficial da União, Brasília, 15 set. 2014. Seção 1, p. 53. 
25. Brasil. Ministério da Saúde. Portaria n.1645, de 02 de outubro de 2015. Dispõe sobre o Programa Nacional de Melhoria do Acesso e da Qualidade da Atenção Básica (PMAQ-AB). Diário Oficial da União, Brasília, 5 out. 2015. Seção 1, p. 668.

26. Santos AF, Sobrinho DF, Araújo LL, Procópio CSD, Lopes EAS, Lima AMLD, et al. Incorporação de Tecnologias de Informação e Comunicação e qualidade na atenção básica em saúde no Brasil. Cad Saúde Pública [Internet]. 2017 [citado 2017 jul. 9];33(5). Disponível em: http:// www.scielo.br/pdf/csp/v33n5/1678-4464-csp-33-05-e00172815.pdf

27. Sanchez-Piedra CA, Jaruseviciene L, Prado-Galbarro FJ, Liseckiene I, Sánchez-Alonso F, García-Pérez S, et al. Factors associated with professional satisfaction in primary care: results from EU primecare project. Eur J Gen Pract. 2017;23(1):114-20.

28. Souza MB, Rocha PM, Sá AB, Uchoa SAC. Trabalho em equipe na atenção primária: a experiência de Portugal. Rev Panam Salud Pública [Internet]. 2013 [citado 2017 abr. 26];33(3). Disponível em: http://www.scielosp.org/pdf/rpsp/v33n3/a05v33n3 